\title{
AN ANALYSIS OF INTERACTIONAL PATTERN BETWEEN TEACHER AND STUDENT IN SMAN 1 CURUP KOTA
}

\author{
Hendi Afriyanto \\ Alamsyah Harahap \\ Azwandi \\ University of Bengkulu \\ Email : tamuaraf@yahoo.co.id
}

\begin{abstract}
This study investigates the interaction pattern in SMAN 1 Curup Kota, based on Coulthard theory (2002). This study analyzed the interaction pattern and type of act used by teacher and students to see the ideal pattern in the classroom. The data analysis shows that (a) the dominant pattern used in the classroom is complete pattern (IRF) and there are also semi-complete pattern (IR) and incomplete pattern (IF); (b) In the type of acts section, the elicitation is the highest followed by informative and starter in the initiation move, reply as the highest act in the response move, and in the follow up accept as the highest followed by comment. It can be concluded that interaction pattern in the classroom is dominantly occured is ideal pattern but it's not good interaction pattern because delimit student opportunity in the classroom
\end{abstract}

Keywords : interaction, classroom discourse and interaction pattern (IRF)

\section{INTRODUCTION}

Interaction is one way of human to do their communication with others. In education sector, the interaction used as a bridge to connect the teacher and student in teaching learning process. It is also become a factor that determine the successfull teaching learning process. As stated by Harmer (2001) he stated that some factors which influence the teaching learning process such as teacher, curriculum, syllabus, materials, methods, media, evaluation, students and interaction. Therefore a teacher should take a look carefully the classroom interaction as the one of the successfull factor in teaching learning process.

Interaction in the classroom is so important because it underpins everything that goes on in classrooms. It is central to teaching, to learning, to managing groups of people and the learning process, and to organize the various tasks and activities that make up classroom practices (Walsh, 2011). Similarly, according to Lier (1996 cited by Walsh, 2006), interaction is the most important thing on the curriculum, if we are to become effective as teachers, we need not only to understand classroom communication, we need to improve it. Therefore the role of interaction in the classroom explicitly is vital to the teaching learning process and the purpose of interaction in the classroom also is to help teacher understand his role in the classroom as facilitator who helps student to use their language through teaching and learning process in order to increase their knowledge about the course therefore teacher can maximize student potential in the classroom.

A study from Lewis (1997), he looks at teacher student interaction in the secondary level of Indonesian context. His findings revealed that English lessons were 
teacher-centred and textbook driven and another study from Maulana, Opdenakker, Stroet, and Bosker (2012) revealed that Indonesian teachers spent most of their time lecturing in front of the classroom therefore there is hardly any interaction with students. In conclusion those research indicated there was a dominancy of teacher in the classroom therefore the interaction is very important to see in the classroom as one of the component in the teaching learning process.

Another study, conducted by Harahap, (2015), the purpose of this study is to describe and explain the phenomenon of the practice English Language Learning with a particular focus on the interpersonal relationship between teacher and student through the study of classroom discourse analysis. The result of this research concluded that teacher-student act in the classroom discourse of teaching English in high school was dominated by teacher's act and speech act that reached $94 \%$ out of the total acts of English classroom discourse. Furthermore, the structure of classroom discourse of teaching English in high school was in an asymetric form which was not accordance with the learning concept based on the recent English teaching and learning approach.

Ginarsih (2013), conducted study in senior junior high school in Lampung, the result revealed that classroom interaction process in English speaking class is quiet satisfaction where the high percentages of student inform (33.79\%), students elicit $(14.95 \%)$ and teacher elicit (16.89\%), teacher inform (14.12\%), check (13.01\%), teacher direct $(7.20 \%)$ indicate that students have their own awareness to get involved in the activity and to participate as well as to interact actively during the teaching learning process.

A teacher also need to see the pattern of the interaction. It is neccesary to understand the pattern that possibly occured in order to help teacher to understand his role in the classroom not only as a controller, manager, director, or resource but also as facilitator (Brown, 2000). A facilitator descibed as facilitating the process of the learning and making learning easier to the students as the result an ideal interaction will be possible to achieve in the classroom As stated in Coulthard, (2002); Walsh, (2006) \& (2011) ; Bloome , (2005) and Cazden ,2001) the most common pattern which is occured in the classroom is IRF (InitiationResponse- Follow up). Implicitly the ideal pattern found in the classroom is IRF (Initiation-Response-Follow Up). Structurally, (IRF) means an initiation or question from teacher, response or answer from student and follow up or feedback from teacher. Only a few studies which focus on the pattern of interaction in the secondary school level in Indonesian context, for example Ginarsih (2013), conducted study in senior junior high school in Lampung, the result revealed that classroom interaction process in English speaking class is quiet satisfaction where the high percentages of student inform $(33.79 \%)$, students elicit $(14.95 \%)$ and teacher elicit (16.89\%), teacher inform $(14.12 \%)$, check (13.01\%), teacher direct $(7.20 \%)$ indicate that students have their own awareness to get involved in the activity and to participate as well as to interact actively during the teaching learning process. There are plenty studies about interaction pattern in non Indonesian school context. For example studies from Liu (2012), Atkin (2001) and Matthew (2010). These researchers found that IRF pattern dominated interaction in the classroom and teacher was dominant in talking in the classroom. However only a few studies conducting a research about interaction pattern in the senior high school level. Whereas the interaction pattern is one of the important factor to see, as explained before by understanding interaction pattern teacher will realize their actual role in the classroom as a facilitator and able to create as many as opportunity 
for the student to optimize their potential in the classroom. It is one of the reason why the researcher take this topic. There were 2 main questions in this research 1) what patterns of interactions are used in

\section{METHOLOGY}

Researcher designs this research by using qualitative method. It is appropriate design for this study because qualitative research uses a naturalistic approach that seeks to understand phenomena in context-specific settings, such as real world setting where the researcher does not attempt to manipulate the phenomenon of interest (Patton cit.Golafsani, 2003: 600).

The participants of this research are 2 classes from social and science class. Those classes are taught by same teacher. The teacher is also become the object of the classroom ? 2) what is the type of act un the initiation move, response move and follow up move occuring in the classroom?. this research to be observed because teacher got involve in the classroom interaction. Teacher $\mathrm{A}$ who was the subject of this research had been dedicated himself in SMAN 1 Curup Kota more than 20 years and experienced in teaching English. Science class 1 (XI IPA 1) and social class 3 (XI IPS 3) were subject of this research included the teacher

Table 1. Subject of the Research

\begin{tabular}{|c|c|c|c|}
\hline Subjects & Male & Female & Total \\
\hline Teacher & - & 1 & 1 \\
XI Science Class (IPA 1) & 12 & 20 & 32 \\
XI Social Class (IPS 3) & 14 & 18 & 32 \\
\hline
\end{tabular}

This research concerned to the observation instrument as the main instrument in this research. It was taken by seeing the question of the research and set the appropriate instrument according to the research question. The table of analysis of this research was designed based on (Coulthard, 2002) theory, as follows :

Table 2. Observation Instrument

\begin{tabular}{|c|c|c|c|c|c|c|}
\hline No & IRF & Subject & Utterances & Act & Exchange & Line \\
& Move & & & & & \\
\hline & & & & & & \\
\hline
\end{tabular}


The researcher also used 2 video cameras to obtain verbal data from teacher and student in the classroom. There were several steps has been conducted also to

\section{FINDING AND DISCUSSION}

\section{Interaction Pattern In the classroom}

The first objective of this research to classify the pattern of interaction in the classroom. There were certain patterns analyze this study, transcribing the video, coding data, interpreting data and finishing or conclusion.

found there; complete pattern, semi complete pattern and incomplete pattern.

Table 3. Interaction Pattern in the classroom

\begin{tabular}{|llcc|}
\hline No & Type IRF pattern & Frequency & Percentage \\
\hline 1 & Complete Pattern (IRF) & 140 & $\mathbf{3 4 , 0 6 \%}$ \\
2 & Semi Complete Pattern (IR) & 120 & $29,19 \%$ \\
\hline 3 & Incomplete Pattern (IF) & 14 & $\mathbf{3 , 4 1 \%}$ \\
\hline Total & & 274 & $\mathbf{6 6 , 6 6 \%}$ \\
\hline
\end{tabular}

From table 3. complete pattern (IRF) obtained from the classroom only 140 interactions applied or $(34,06 \%)$ from 411 interactions. This result even couldn't reached a half of total interaction found the classroom. In fact this pattern dominated by teacher role in which control the classroom by using teacher elicit. The interaction below is the example of the complete pattern (IRF) in the classroom

\section{Extract 1 (First Meeting, Science Class, Example of IRF)}
4 I Teacher: So the sentence is simple present tense where did you know?
5 R Pupil : From verb
6 F Teacher : From the verbs

From the example above, researcher could construct the pattern as follow :

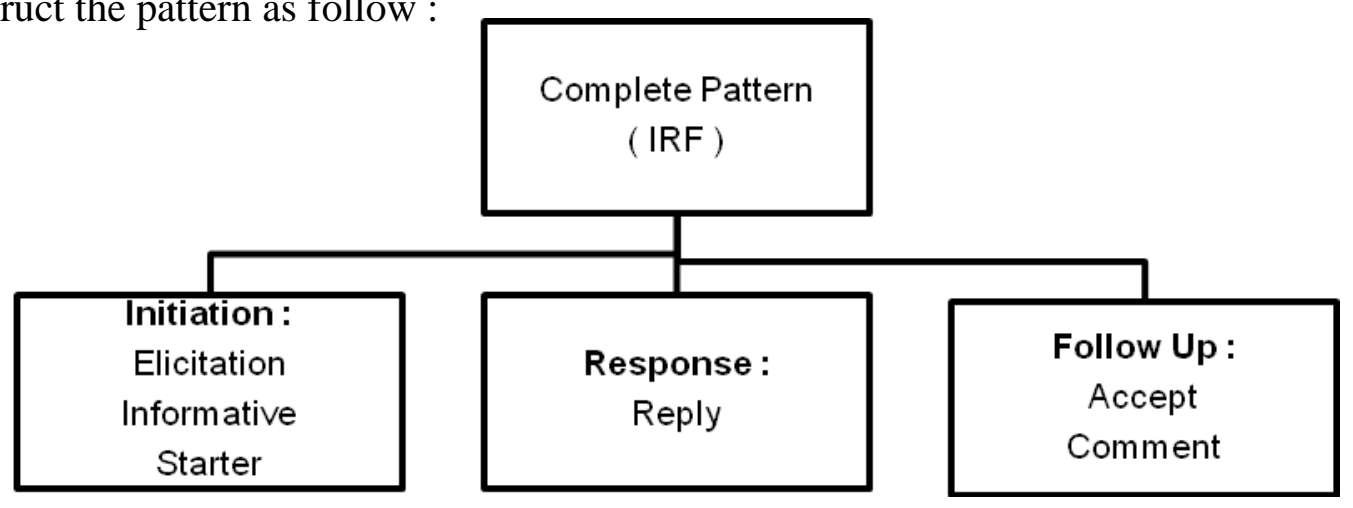


Figure 1 Complete Pattern (IRF)

The example from extract 1 was taken from interaction transcript first meeting science class in line 4, 5 and 6. It shown us where student proposed a question then answered by student and the last teacher accept the answer by using repetition of the student reply. Therefore it constructed a complete pattern (IRF).

The second pattern found in this research is IR. In this research, researcher called semi complete pattern because it was not complete yet. Such IR (initiationresponse) in this term, there is no feedback or follow up from teacher as the completion of the interaction pattern. Based on the table 4.1 from 411 total interactions researcher found there were 120 interactions used IR pattern $(29,9 \%)$. The interaction below is the example of semi complete pattern (Initiation Response)

\section{Extract 2 (First Meeting, Science Class, Example of IR)}

70 I Teacher : What is the meaning of refresh ? corner!

$71 \quad$ R Pupil : Mengulang

From the example above, researcher could construct the pattern as follow :

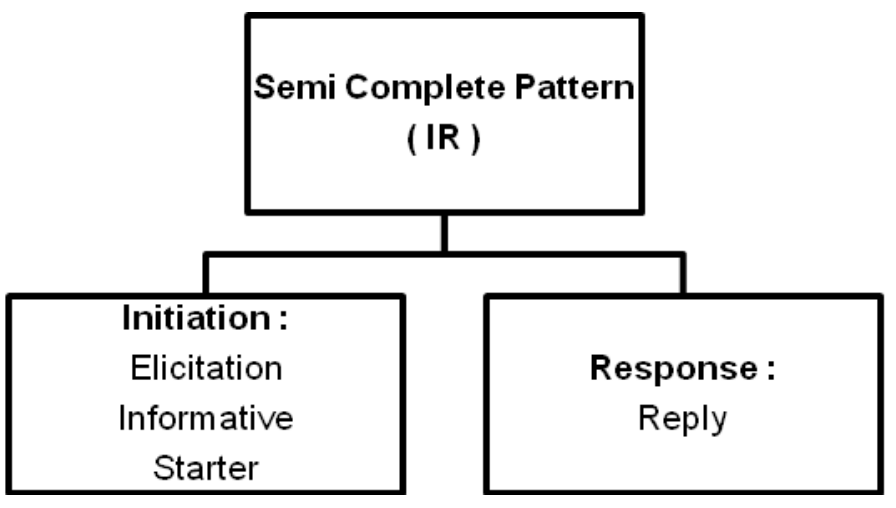

Figure 2. Semi Complete Pattern (IR)

The example of extract 2 was taken from interaction transcript in science class first meeting line 70 and 71 , it was a condition where student initiates by eliciting teacher then replied by teacher, this pattern formed Initiation - Response (IR). 
The last pattern is incomplete pattern, in IF (initiation-follow up) there is no response move from student as a bridge between initiation and follow up move.
Based on the table 4.1 from 411 total interactions researcher found there were 14 interactions used IF pattern $(3,4 \%)$.

\section{Extract 3 (First Meeting, Science Class Example of IF)}

15 I Teacher : The second, we will check to the others or present continous, a rabbit eats a carrot, what is the present continous?

- $\quad$ R Pupil : (Silent)

16 F Teacher : Ya,a rabbit is eating a carrot

From the example above, researcher could construted the pattern displayed in the figure below

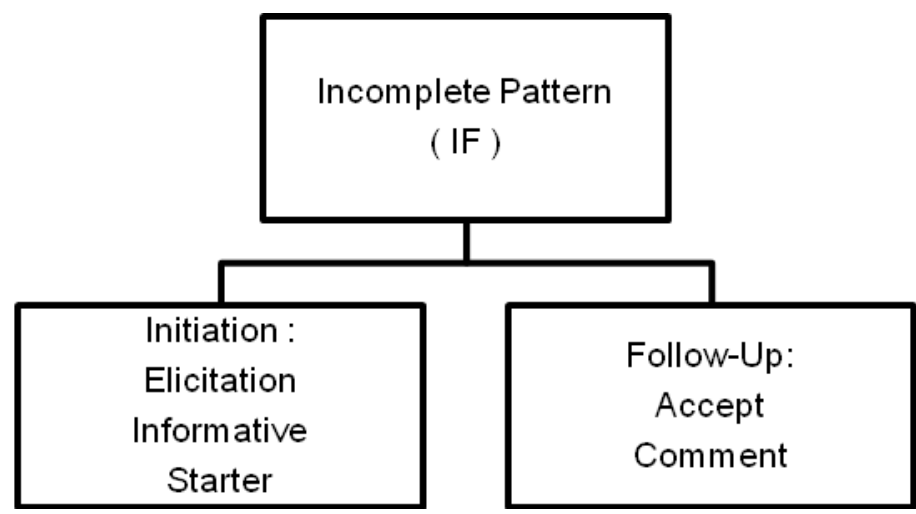

Figure 3. Semi Complete Pattern (IR)

The example of extract 3 was taken from interaction transcript in science class first meeting line 15 and 16 . In extract 3, the teacher asked student about the related course unfortunately student can't answer the question therefore the teacher must answer the question by himself as the result the constructed pattern formed was Initiaton - follow up (IF).

The rest of the interaction for this research categorized as uncategorized pattern because only initiation occured, by means there was no interaction there. It is (I) or only initiation. In this case only initiation could occur without using response and follow up, such as teacher inform, teacher elicit without response or only checking student progress without asking their response.

Based on the table 4.1 the amount of only initiation as single move is in the second position after completed pattern (IRF). It indicated by 137 utterances used this uncategorized pattern from 411 total interactions in the classroom. This number was filled by teacher inform, unresponsed question from teacher, teacher direct and check in classroom. The following 
example shown the example uncategorized pattern in this study:

Extract 4 (Social Class, First Meeting, example of uncategorized pattern)

7 I Teacher : Do you want to write the sentence ?

- $\mathrm{R}$ Pupil : (Silent)

In the extract 4 line 7, the teacher the whiteboard but no response from directed student to write the sentence in student.

\section{Extract 5 (Social Class, First Meeting, example of uncategorized pattern)}

12 I Teacher : Apa artinya listen and pay attention?

- $\quad$ R Pupil : (Silent)

In the extract 5 line 12, the teacher asked student by asking them, but the student cant reply the question as the

\section{Extract 6 (Social Class,First Meeting, example of incomplete pattern)}

87 I Teacher : Ini seperti yang telah saya sampaikan kepada anda memang pernah terjadi secara kebetulan kalo saya sendiri memang terjadi pada ponakan saya anak adik saya itu yang terpintar ya jadi yang terpintar waktu itu adalah di sumatra barat sesumatra barat dia tinggalnya di pelosok di daerah lagi jauh miskin lagi sudah jauh misin dia bisa terpintar di sumatera barat itu kan enak itu nahhh sampe sampe dia sekolah itu saja gratis lagi sudah sekolah gratis dia buku nggak tapi disuruh njelaskan dapat semuanya punya (.) cuma kalo malam memang dia nggak pernah belajar, malam itu kerjaanya itu hanya nonton TV ya jadi kalo nggak nonton tv dia maen game ya seperti itu ternyata hanya di sekolah itulah dan dia yang terpintar sampe ujian nasional hanya satu nilainya yang nyaa yang tidak sepuluh atau nilai seratus.

- $\quad$ R Pupil : (Silent)

In the extract 6 line 87, the teacher gives information to the student, but there was

Extract 7 (Social Class, First Meeting, example of incomplete pattern) no student response the information from the teacher. 
122 I Teacher : Sudah semuanya ini ?

$$
\text { R Pupil : (Silent) }
$$

In extract 7 line 122, where the teacher is checking his student task by asking them but no response or reply that initiation.

\section{Act Types of In the Classroom}

The second research question of this research is looking for the acts of each move. The analysis of act in this research held in 2 classes (science and social class). In this research move divided into 3 parts; initiation move, response move and follow up move based on model Sinclair and Coulthard, in Coulthard (2002).

There are 22 kind of acts used to match with 3 kinds of moves (initiation, response and follow up). Each act has their own function in the utterance, to ease researcher in determining the kinds of act while the observation, researcher used linguistic features that attached in the appendic. It is used to give a guidance for researcher about the characteristic of each act. In order to organize the data, researcher has served it into the appropriate table. The result can be seen in the following table

Table 4. Type of acts used in the classroom interaction

\begin{tabular}{|c|c|c|c|c|}
\hline \multirow[t]{2}{*}{ No } & \multirow[t]{2}{*}{ Types of Act } & \multicolumn{3}{|c|}{ Move } \\
\hline & & $\begin{array}{l}\text { Initiation } \\
\text { (Teacher) }\end{array}$ & $\begin{array}{l}\text { Response } \\
\text { (Student) }\end{array}$ & $\begin{array}{l}\text { Follow Up } \\
\text { (Teacher) }\end{array}$ \\
\hline 1 & Elicitation & 270* & 11 & - \\
\hline 2 & Starter & 55 & - & - \\
\hline 3 & Marker & 42 & - & - \\
\hline 4 & Check & 19 & - & - \\
\hline 5 & Directive & 48 & - & - \\
\hline 6 & Clue & 1 & - & - \\
\hline 7 & Prompt & 7 & - & - \\
\hline 8 & Cue & 16 & - & - \\
\hline 9 & Bid & 3 & 7 & - \\
\hline 10 & Nominate & 8 & - & - \\
\hline 11 & Informative & 97 & - & - \\
\hline
\end{tabular}




\begin{tabular}{|llccc|}
\hline 12 & Reply & - & $207 *$ & 25 \\
\hline 13 & React & - & 13 & - \\
\hline 14 & Acknowledge & - & 17 & - \\
15 & Evaluate & - & - & 10 \\
16 & Accept & - & - & $108 *$ \\
17 & Comment & - & - & 70 \\
18 & Loop & - & - & - \\
19 & Aside & - & - & - \\
\hline 20 & Conclusion & 6 & - & - \\
21 & Metastatement & 6 & - & - \\
\hline 22 & Silent Stress & 42 & - & - \\
& Total Act & 620 & 255 & 213 \\
& Percentage & $\mathbf{5 6 , 9 8} \%$ & $\mathbf{2 3 , 4 3 \%}$ & $19,59 \%$ \\
\hline & & & & \\
\hline
\end{tabular}

Based on table 4.2 In initiation move, researcher obtained elicitation, directives, prompt, cue, nominate, informative, starter, marker, check, clue , bid, conclusion, metastatement and silent stress. By looking at this data, elicitation act really dominated, it indicated by high proportion of elicitation 270 times in the interaction that found bigger than any acts in the initiation move. It was also followed by informative and starter in the second and third position. Response move occurs when initiation accepted or need to be responded. Based on table 4.2 move consisted of reply, react, bid, elicitation and acknowledge. It is regularly true that this move refer to student or student is more dominant in this move but sometimes this move also used by teacher because teacher need to answer student's elicitation. This data shown indicated initiation move still affected response move, it is shown by the higher frequency of elicitation, the higher possibilty also frequency of reply occured, in this study, researcher obtained 207 replies in the classroom. But in this move there was elicitation act emerged in this study. It was about 11 elicitation acts.

Meanwhile in the follow up, it is consisted of evaluate, comment and accept. This move used to respond the response move. For instance when student can answer teacher question, teacher sometimes giving reply, comment, accept or evaluate the student answer. In this act, accept was (108) times found in this study and dominated the other act in this move. It was followed by comment in the second position. Based on the observation sometimes accept and comment found in one utterance. But in this move there was relpy act emerged in this study. It was about 25 reply acts. 


\section{Time Duration of Each Move}

In this research the researcher calculated the time duration of each move in order to know how much those moves applied in the classroom. It is neccessary to do to see the length of student and teacher talk in the classroom. The amount of teacher and student talk in this research represented by initiation from teacher, response from student and follow up from teacher. The problem of quality of each move itself also used as one of the reason why researcher put this data in this research even if there is no research question about this term.

At the field, the courses should be done for 90 minutes, in fact the the duration of courses decreased because of some reason; first, the day when the researcher did observation was Friday, it's a day when there was an event before students coming to the class such as, Yasinan Bersama and doing exercises as the effect it consumed much time of the courses, it could be 10 - 15 minutes took course duration. Second, teacher and student also consumed much time walked to the class or teacher and student need time to come to the class. When teacher come to the class, there is still student in outside the classroom therefore teacher must wait the students, and also when all students attended the class, they must wait the teacher walked to the class, it is also consumed much time between 5-10 minutes. The result of each moves consumed the duration in this research is mentioned in table below :

Table 4. Time Allocation of Classroom Interaction

\begin{tabular}{|lccc|}
\hline No & Pattern & Minute & Percentage \\
\hline $\mathbf{1}$ & Initiation (I) & $\mathbf{1 8 0}$ minutes & $\mathbf{6 9 , 2 \%}$ \\
2 & Response (R) & $\mathbf{2 7}$ minutes & $\mathbf{1 0 , 3 \%}$ \\
$\mathbf{3}$ & Follow Up (F) & $\mathbf{5 3}$ minutes & $\mathbf{2 0 , 3 \%}$ \\
\hline & Total & $\mathbf{2 6 0}$ minute & $\mathbf{1 0 0 \%}$ \\
\hline
\end{tabular}

Based on the table above, The time spent dominated by Initiation move. It indicated by 180 minute or 69,2 percent of the course was spent by initiation move. It occured because teacher in initiation move giving their information, experience and the courses before coming to the elicitation.

After initiation there was follow up with 53 minutes or 20,3 percent, in this move also teacher has a big deal role to talk after student response and also sometimes it wasted too much time by comment the response from the student. The last was response from student. In this move student's role in this study dominant to be a responder of the initiation, so when the elicitation, direction or informing applied by teacher, there students replied, react or sometimes giving back question as the response. 


\section{DISCUSSION}

Based on the result or finding, the complete pattern occured more in the classroom or dominated the interaction pattern in the classroom. Based on researcher observation, this pattern occured more beacuse teacher wanted to facilitate student to follow the course by giving a lot of elicitation. As stated by Walsh (2002), a teacher should maximize student involvement and facilitate student to contribute to the discourse. By using complete pattern (IRF) automatically teacher has provided and facilitated students to contribute to the discourse or getting involve to the interaction in the classroom.

It was also in line with some previous studies by Liu (2012), Atkin (2001) and Matthew (2010). These researchers found that complete pattern (IRF) dominated interaction in the classroom. As the conclusion the complete (IRF) pattern still was the ideal pattern used in the classroom. It was also indicated that the teacher still be the initiator and student as responder. It is appropriate with (Walsh, 2006) he stated that the underlying structure of second language lessons is typically represented by sequences of discourse 'moves' $\mathrm{IR}(\mathrm{E} / \mathrm{F})$, where $\mathrm{I}$ is teacher initiation, $\mathrm{R}$ is learner response and $\mathrm{E} / \mathrm{F}$ is an optional evaluation or feedback by the teacher. It means that the ideal pattern in the classroom was complete pattern (IRF).

Act is smaller part of classroom interaction model of Coulthard (2002). Regarding to the result, in the initiation move, there were 14 acts among of them elicitation act as the highest act. It implied that teacher was more dominant in opening the interaction, it is also as the consequences of the responsibility from the teacher as an educator, teacher should help their student to understand the input that they receive from the teacher, it called as "modifiying speech" (Walsh,2006), therefore teacher simplied their courses by using a lot of question to help student comprehend the courses easier.

Beside the elicitation also there was starter and informative in this move that has a little significant different amount, it implied that teacher also helped the student to concentrate to the course and be focus with the discourse by using starter and informative, in other side it was also spent a lot of time therefore teacher still be dominant in this move.

In the response move, there were 5 acts among of them reply as the highest. It implied that student only speak when the teacher asked them question. It indicated students were not active to ask a question in the course or self-initiated to give an opinion, asking a question even giving a new information. It was also as an effect of the display question delivered by teacher, therefore student didn't try to think and negotiate with the teacher about the answer of the question.

Then in the follow up move, there were 4 acts among of them accept is the highest act. It implied that teacher only accepted the response from the student, it could be happened when a teacher only giving a display question which the answer has been known by teacher, if the teacher gave the display question, and the student ansewered it true, as the consequence the teacher only accept the response or reply without any comments, If teacher gave them a referential question which need student understanding and comprehend, the follow up may be different, because this kind of question need to be analyzed first.

Beside the accept, comment also has big frequencies in this research, it implied that teacher also appreiciated the student's reply by using comment but the comment of the teacher sometimes out of the topic of the course therefore make the students bored and teacher kept talking and dominated the classroom.

Based on the result, also teacher acts is bigger than students act. It implied that the 
role of student was isolated only to response move, in other words the centrality of the courses still in teacher and it's appropriate with Walsh (2006) and Coulthard (2002) that the structure of initiation for teacher, response for student and follow up for teacher. This result is also quietly similar with the result from Harahap (2015) who conducted his research in SMA Budhi Warman II Jakarta, the result indicated the discourse acts from teacher was bigger than students act and teacher dominated the course in the classroom.

In addition from 540 minutes as the predicition of total duration of English course in the classroom was not match in the field, from 6 meetings only 260 minutes applied, it happened because the time spent for the course has been cut by the task given by teacher to the student and waiting for students and teacher coming to the classroom also spent much time 5-10 minutes. Based on result also, among of the moves, the time duration of initiation move was the highest. It implied that teacher still dominated the classroom especially in the time duration.

Whereas students need more time to practice their English in the classroom or it indicated that the opportunity of the student to practice their English is so limited. Therefore the teacher should able to drive and produce more interaction in the classroom. This condition was reflected from the condition in the classroom. It also proved by more than 69,2 percent teacher took control the classroom through his talk, thus it gave us a description why teacher talked more than student in the classroom.

This result also in line with the studies from Lewis (1997), Maulana (2012) and Nurmasita (2010) that teacher still lecturing in the classroom, teacher dominancy in talking in the classroom and teacher spent more time than students therefore it could not maximize student involvement in the classrroom.
In fact, those results implicitly stated that the ideal pattern in the classroom such as complete pattern (IRF) has been not determined as a good interaction in the classroom because the limited involvement from student. Nunan (1991) pointed that excessive teacher talk should be avoided to give students more opportunities to produce comprehensible output themselves. Therefore the ideal pattern could be completed as a good interaction also if the student talk more in the classroom not teacher, a teacher only facilitator that support the student in the classroom

This condition was appropriate connected with McKay (2003) who suggests that Communicative Language Teaching (CLT) may not fit in straightforwardly with Asian educational culture. It was also compared with other study such as Maulana (2012) and Lewis (1997) which the result was indonesian teacher was lecturing. Not only in Indonesia, it was also found in Japan and China that believe as the advance country from Asia. Hing (2013) China learners was using rote learning, the student was passive larner and teacher was an authotarian and the student was obedient to keep silence in learning.

It indicated Asian learner such as Indonesia, China also was not ready to accept English as the second language.It indicated by the cultural effect from each countries that build the characters of the learner itself. Indonesia could be apparently and closely with japanese education sector when the invasion of Japanese for 3,5 years as collonial in Indonesia also has planted the same culture in Indonesia culture.

Beside the cultural factor, the result of this research also awake us about our pedagogical system where student must be given as much as opportunity to contribute in the classroom. Then we couldn't generalize all student have the same ability because they were from different background knowledge and linguistic 
capabilities. The most important from the result of this research was about how teacher can improve the interaction in the classroom by helping student to be a risk

\section{CONCLUSION}

This study attemps to find out the pattern of interaction in the classroom and act type that used in the classroom. This conclusion was taken from analysis in chapter 4. Firstly, the result indicated that there are 3 kinds of pattern found in the classroom; 1) complete pattern (IRF), 2) semi complete pattern (IR and IF), 3) and incomplete pattern (I). The dominant pattern found in the classroom is complete pattern (IRF).

Secondly, the result indicated that each move has their own dominant act, in initiation move, elicitation as the the

\section{REFERENCES}

Atkin, Andrew (2010).Sinclair and Coulthard's 'IRF' model in a oneto-one classroom: an analysis. Retrieved on $13^{\text {th }}$ August 2016 http://ccsenet.org

Bloome. David (2005).Discourse analysis and the study of classroom language and literacy event. New Jersey: Lawrence Erlbaum Associates :

B.Cazden.Courtney (2001). Classroom Discourse: The language of teaching and Learning. Portsmouth: Heinemann

Coulthard .M .(2002). Advances in Spoken Discourse Analysis. New York:Routledge

Ginarsih. Inggar (2013). An Analysis Of Classroom Interaction At The Second Year of Smp 17 Gedongtataan. Retrieved on $12^{\text {th }}$ August 2016. http:// digilib.unila.ac.id/6951/

Harmer, J. (2001). The Practice of Language Teaching, UK : Longman taker, high motivated and handled their anxiety to improve the quality of interaction.

dominant act, in the response move reply as the dominant act and in the follow up move accept as the dominant act there.

In conclusion, the ideal pattern has been discovered in this research and dominated the interaction pattern in the classroom. However it was dominated by teacher talk, therefore the ideal pattern in this research was not good enough to give the opportunity for student to develop their potential especially in speaking English. It is supported by the acts and time duration for teacher and student to talk.

Harahap, Alamsyah. (2015). TeacherStudents Discourse in English Teaching at High School (Classroom Discourse Anlaysis). Retrieved on $15^{\text {th }}$ November

Helena, Hing (2013). Characteristics Chinese Student's Learning Style

Liu. (2012). A Case Study on College English Classroom Discourse. Retrieved on $15^{\text {th }}$ September 2016, http://google scholar.com

Lewis, R. (1997). Indonesian students' learning styles. EA Journal, 14(2), 2732. Retrieved on $15^{\text {th }}$ September 2016, http://google scholar.com

Maulana, R., Opdenakker, M. C., Stroet, K., \& Bosker, R. (2012). Observed lesson structure during the first year of secondary education: Exploration of change and link with academic engagement. Teaching and Teacher Education, 28(6), 835-850

McKay, S. (2003). The cultural basis of teaching English as an international language. TESOL Matters, 13(4), $1-2$. 
Matthew.(2010). Applying the Sinclair and Coulthard Model ofdiscourse analysis to $-\mathrm{a}$ student centered

Nahid Golafshani. (2003). Understanding Reliability and Validity in Qualitative Research. Retrieved on $18 \mathrm{t}^{\mathrm{h}} \quad$ September 2016. http://www.nova.edu/ssss/QR/QR8 -4/golafshani.pdf

Nunan, D. (1991). Language teaching methodology: A textbook for teachers. New Jersey: Prentice Hall.

Nurmasitah. Sita (2010). A Study of Classroom Interaction

Characteristics in a Geography Class Conducted in English: The Case at Year Ten of an Immersion Class in SMAN 2 Semarang, Retrieved on $12^{\text {th }}$ August 2016 http:// eprints.undip.ac.id/23803/

Walsh, Steve (2011).Exploring Classroom Discourse.UK: University of Nottingham

Walsh. Steve (2006).Investigating Classroom Discourse, New York :Routledge
EFL classroom. Retrieved on $29^{\text {th }}$

August 2016 http:// Eduacademia.com 